\title{
Reaction of o-bromoaryl- and o-bromoarylalkyl phthalimides with n-butyllithium at low temperatures
}

\begin{abstract}
In a study designed to determine chemoselectivity of nucleophilic addition versus brominelithium exchange, addition of $n$-butyllithium to $o$-bromoaryl- and $o$-bromo- arylalkyl phthalimides at low temperature results in clean addition to the imide carbonyl in lieu of bromine-lithium exchange thereby affording good to excellent yields of 3- $n$-butyl-3hydroxyisoindolin-1-ones containing a bromoarene moiety. This methodology has potential for the preparation of a variety of highly functionalized nitrogen heterocycles.
\end{abstract}

Keywords: $o$-bromoaryl phthalimides, $o$-bromoarylalkyl phthalimides, bromine-lithium exchange studies, 2-bromoaryl-3- $n$-butylhydroxyisoindolin-1-ones, 2-bromoarylalkyl-3- $n$ butylhydroxyisoindolin-1-ones
Volume 2 Issue 5 - 2018

\author{
David A Hunt \\ Department of Chemistry, The College of New Jersey, USA
}

Correspondence: David A Hunt, Professor of Chemistry, Department of Chemistry, The College of New Jersey, 2000 Pennington Road, Ewing, NJ 08628, USA, Tel (609) 77/3 174, Email hint@tcnj.edu

Received: September 17, 2018 | Published: October 17, 2018

\section{Introduction}

The work of Parham, Jones and Sayed, ${ }^{1}$ which demonstrates that bromine-lithium exchange, occurs in preference to carbonyl addition in aromatic amide derivatives of $o$-bromo- $\beta$-phenylpropionic acid, led to the consideration of using $o$-bromoaryl phthalimides $1 \mathrm{a}-\mathrm{c}$ as precursors for the preparation of multi-ring nitrogen heterocycles and for elaborations of aromatic systems requiring an amine-protecting group (Figure 1). While the chemistry of the addition of Grignard and organolithium reagents to phthalimides is well known, ${ }^{2}$ to the best of our knowledge, attempts to carry out the addition of the these reagents to brominated phthalimide derivatives such as 1a-c have not been studied.<smiles>O=C1c2ccccc2C(=O)N1Cc1ccccc1Br</smiles>

$1 \mathrm{a}, \mathrm{n}=0$

1b. $n=1$

$1 c, n=2$

Figure I o-bromoaryl phthalimides Ia-c as precursors for the preparation of multi-ring nitrogen heterocycles and for elaborations of aromatic systems requiring an amine-protecting group.

\section{Results and discussion}

Even at low temperatures $\left(\mathrm{ca} .-100^{\circ} \mathrm{C}\right)$, bromine-lithium exchange to provide intermediate 2 proved fruitless in each case, presumably due to the greater electro- philicity of the imide carbonyl system compared to the aryl bromide. The major product cleanly formed in each case was the addition product arising from attack of the $n$-butyllithium on the imide carbonyl group (Compound 3a-c, Figure 2).<smiles>O=C1c2ccccc2C(=O)N1Cc1ccccc1Br</smiles>

1a, $n=0$

1b. $n=1$ 1c, $n=2$<smiles>CCCC[C@]1(O)c2ccccc2C(=O)N1Cc1ccccc1Br</smiles>

3a, $\mathrm{n}=0$

3b. $\mathrm{n}=1$

$3 c, n=2$

Figure $\mathbf{2}$ The major product cleanly formed in each case was the addition product arising from attack of the n-butyl-lithium on the imide carbonyl group.

While the reaction of Grignard reagents with phthalimides is well known and has proven to be a valuable method for the preparation of alkylidenephthalimidines, ${ }^{3}$ heating is typically necessary for the reaction. In the case of the low temperature exchange attempts of these systems, aliquotting experiments revealed that substantial butylation had occurred after 30 minutes at $-100^{\circ} \mathrm{C}$. Compound 3 a was determined to be a mixture of rotamers based on ${ }^{13} \mathrm{C}$ NMR analysis, presumably due to steric inhibition of free rotation about the phenyl $\mathrm{C}-\mathrm{N}$ bond. The homologs $3 \mathrm{~b}$ and $3 \mathrm{c}$ did not exhibit this behavior based of ${ }^{13} \mathrm{C}$ NMR analysis. The ${ }^{1} \mathrm{H}$ NMR spectrum of $3 \mathrm{~b}$ revealed the presence of an $\mathrm{AB}$ pattern for the benzylic protons. Presumably, this 
is not due to rotational barriers since this was not observed in the ${ }^{13} \mathrm{C}$ NMR spectrum.

\section{Experimental}

\section{General}

Melting points were determined on a Mel-Temp heating block in open capillary tubes and are uncorrected. ${ }^{1} \mathrm{H}$ NMR spectra were obtained on a Varian Gemini 300MHz NMR with tetramethylsilane as an internal reference. ${ }^{13} \mathrm{C}$ NMR spectra $(75 \mathrm{MHz})$ were obtained utilizing $\mathrm{CDCl}_{3}$ lock. IR data were recorded on a Perkin-Elmer 2000 FT-IR spectrometer. Elemental analyses were performed by MHW Laboratories, Phoenix, AZ. All starting material, reagents, and solvents were reagent grade and were used without additional purification. Tetrahydrofuran was dried over lithium aluminum hydride.

\section{Preparation of $\mathrm{N}$-(o-bromophenyl) phthalimide ( I a $)^{4}$}

To a $500 \mathrm{~mL}$ Erlenmeyer flask equipped with a magnetic stirrer were added $o$-bromo-aniline $(20.40 \mathrm{~g} ; 0.119 \mathrm{~mol})$, phthalic acid $(19.69 \mathrm{~g}$; $0.119 \mathrm{~mol})$, and acetic acid $(150 \mathrm{~mL})$ and the resulting mixture was heated with stirring to $100^{\circ} \mathrm{C}$ (oil bath) for $14 \mathrm{~h}$. The mixture was then allowed to cool and was poured into water $(400 \mathrm{~mL})$. The resulting crystalline precipitate was collected by vacuum filtration and was airdried to constant weight (32.83g, 91\%). The compound was purified by recrystallization from ethanol-chloroform (1:1) to provide purified 1a as white needles $(31.24 \mathrm{~g}, 87 \%)$, mp $126-27.5^{\circ} \mathrm{C}$; IR $(\mathrm{KBr})$ : $1675 \mathrm{~cm}^{-1} ;{ }^{1} \mathrm{H}$ NMR $\left(300 \mathrm{MHz}, \mathrm{CDCl}_{3}\right): \delta 7.22-8.12(\mathrm{~m}, \mathrm{ArH})$. Anal Calcd for $\mathrm{C}_{14} \mathrm{H}_{8} \mathrm{BrNO}_{2}$ : C, 55.63; H, 2.65; Br, 26.49; N, 4.64. Found: C, 55.65; H, 2.79; Br, 26.57; N, 4.48.

\section{Preparation of $\mathbf{N}$-(o-bromobenzyl) phthalimide (I b) ${ }^{5}$}

To a solution of $o$-bromobenzyl bromide $(32.45 \mathrm{~g} ; 0.13 \mathrm{~mol})$ in DMF $(75 \mathrm{~mL})$ in a $500 \mathrm{~mL}$ Erlenmeyer flask equipped with a magnetic stirrer was added potassium phthalimide $(25.90 \mathrm{~g} ; 0.14 \mathrm{~mol})$. An exothermic reaction ensued $\left(70^{\circ} \mathrm{C}\right.$ within $\left.8 \mathrm{~min}\right)$, and stirring was continued until the mixture cooled to room temperature (4h). The mixture was then diluted with chloroform $(200 \mathrm{~mL})$ and the resulting mixture was poured into water $(300 \mathrm{~mL})$. The aqueous phase was separated and was extracted with chloroform $(2 \times 50 \mathrm{~mL})$ The combined organics were then washed sequentially with aqueous $\mathrm{NaOH}(0.2 \mathrm{~N}, 300 \mathrm{~mL})$ and water $(300 \mathrm{~mL})$. The organics were dried, filtered, and concentrated in vacuo to afford $1 \mathrm{~b}(33.47 \mathrm{~g}, 82 \%)$ as a brown semisolid, which was triturated with diethyl ether to provide fine white needles $(32.00 \mathrm{~g}, 78 \%), \mathrm{mp} 162-64^{\circ} \mathrm{C}$; IR (KBr): $1609 \mathrm{~cm}$ 1; ' ${ }^{1} \mathrm{H}$ NMR (300 MHz, $\mathrm{CDCl}_{3}$ ): $\delta 5.09$ (s, 2, benzylic $\mathrm{CH}_{2}$ ), 7.12-7.43 (m, $3 \mathrm{ArH})$, 7.50-7.67 (m, $1 \mathrm{ArH}), 7.80-8.12$ (m, 4, ArH). Anal. Calcd for $\mathrm{C}_{15} \mathrm{H}_{10} \mathrm{BrNO}_{2}$ : $\mathrm{C}, 56.96 ; \mathrm{H}, 3.16 ; \mathrm{Br}, 25.32 ; \mathrm{N}, 4.43$. Found: $\mathrm{C}$ $56.84 ; \mathrm{H}, 3.12 ; \mathrm{Br}, 25.41 ; \mathrm{N}, 4.27$

\section{Preparation of $\quad \mathrm{N}$-(o-bromo- $\beta$-phenylethyl) phthalimide (I c $)^{6}$}

$o$-Bromo- $\beta$-phenylethyl bromide $(90.65 \mathrm{~g} ; 0.343 \mathrm{~mol})$ was place in a $1 \mathrm{~L}$ Erlenmeyer flask equipped with a magnetic stirrer and oil bath and was dissolved in DMF $(280 \mathrm{~mL})$. To the stirred solution was added potassium phthalimide $(66.64 \mathrm{~g} ; 0.360 \mathrm{~mol})$ and the resulting mixture was heated to $90^{\circ} \mathrm{C}$ with stirring for $15 \mathrm{~h}$. The mixture was allowed to cool and was diluted with chloroform $(400 \mathrm{~mL})$. The mixture was transferred to a seperatory funnel containing water $(300 \mathrm{~mL})$. After vigorous mixing, the aqueous phase was removed and extracted with chloroform $(2 \times 50 \mathrm{~mL})$. The combined chloroform layers were washed sequentially with aqueous $\mathrm{NaOH}(0.2 \mathrm{~N}, 300 \mathrm{~mL})$ and water $(300 \mathrm{~mL})$. The organics were dried, filtered, and concentrated in vacuo to afford $1 \mathrm{c}$ as a pale yellow solid $(94.27 \mathrm{~g}, 83 \%)$ recrystallized from 7:3 ligroin-methanol to provide fine white needles, mp $96.5-98^{\circ} \mathrm{C}$; IR (KBr): $1690 \mathrm{~cm}^{-1} ;{ }^{1} \mathrm{H}$ NMR $\left(300 \mathrm{MHz}, \mathrm{CDCl}_{3}\right): \delta 3.16$ (t, $2, \mathrm{~J}=8 \mathrm{~Hz}$, $\mathrm{CH}_{2}$ ), 4.02 (t, 2, J=8Hz, benzylic $\mathrm{CH}_{2}$ ), 7.00-7.96 (m, 8, ArH). Anal. Calcd for $\mathrm{C}_{16} \mathrm{H}_{12} \mathrm{BrNO}_{2}$ : C, 58.18; $\mathrm{H}, 3.64 ; \mathrm{Br}, 24.24 ; \mathrm{N}, 4.24$. Found: C, 58.06; H, 3.60; Br, 24.43; N, 4.04.

\section{General procedure for the reaction of $\mathbf{n}$-butyllithium with N-(o-bromoaryl) phthalimides. Preparation of Compounds 3a-c}

The bromoaryl phthalimide (1a-c) was dissolved in anhydrous THF $(125 \mathrm{~mL})$ and hexane $6(30 \mathrm{~mL})$, and the resulting solution was placed into a three-neck $250 \mathrm{~mL}$ round bottom flask equipped with an overhead stirrer, addition funnel, low temperature thermometer and $\mathrm{N}_{2}$ inlet, and low temperature ( $\mathrm{LN}_{2} /$ diethyl ether) bath. The mixture was cooled to $-100^{\circ} \mathrm{C}$, and n-butyllithium (1.0molar equivalent) was added at such a rate so as to maintain the temperature below $-95^{\circ} \mathrm{C}$. After the addition was complete, the mixture was stirred at $-100^{\circ} \mathrm{C}$ for $1 \mathrm{~h}$. The mixture was then allowed to warm to room temperature ( $2 \mathrm{~h})$ and was poured into water $(200 \mathrm{~mL})$. The organic phase was separated from the aqueous phase and the aqueous phase was extracted with diethyl ether $(3 \times 125 \mathrm{~mL})$. The combined organics were dried $\left(\mathrm{MgSO}_{4}\right)$, filtered and concentrated in vacuo. The crude products were purified by recrystallization.

2-(2-Bromophenyl)-3-butyl-3-hydroxyisoindolin-1-one (mixture of rotamers) was isolated as white needles $(3.45 \mathrm{~g}, 64 \%)$ after recrystallization from benzene-petroleum ether (1:4) by reaction of N-o-(bromophenyl) phthalimide (1a, 4.53g; $0.015 \mathrm{~mol})$ with n-butyllithium $\left(6.52 \mathrm{~mL} ; 0.015 \mathrm{~mol} / 2.3 \mathrm{M}\right.$ in hexane), $\mathrm{mp} 146-46.5^{\circ} \mathrm{C}$; IR (KBr): 3360, 3050, 2925, 1665, 1610, 1470, 1380, 1110, 1020 , $860,830,760 \mathrm{~cm}^{-1} ;{ }^{1} \mathrm{H}$ NMR $\left(300 \mathrm{MHz}, \mathrm{CDCl}_{3}\right): \delta 0.82(\mathrm{t}, 3, \mathrm{~J}=7 \mathrm{~Hz}$, $\left.\mathrm{CH}_{3}\right), 1.02-1.46\left(\mathrm{~m}, 4, \mathrm{CH}_{2} \mathrm{CH}_{2}\right), 1.80-2.22\left(\mathrm{~m}, 2, \mathrm{CH}_{2}\right), 2.96$ (bd s, 1, OH), 7.08-7.82 (m, $8 \mathrm{ArH}) ;{ }^{13} \mathrm{C}$ NMR $\left(75 \mathrm{MHz}, \mathrm{CDCl}_{3}\right): \delta 18.40$, $29.80,30.04,34.60,48.00,48.50,93.78,94.47,122.46,123.10$, $124.36,124.79,126.78,128.68,128.76,129.29,130.16,130.33$, $130.69,131.24,132.25,133.39,134.01,134.73,134.95,135.31$, 135.83, 148.21, 148.74, 166.92, 167.92. Anal. Calcd for $\mathrm{C}_{18} \mathrm{H}_{18} \mathrm{BrNO}_{2}$ : C, 60.00; H, 5.00; Br, 22.22; N, 3.89. Found: C, 59.92; H, 5.09; Br, $21.98 ; \mathrm{N}, 3.60$

2-(2-Bromobenzyl)-3-butyl-3-hydroxyisoindolin-1-one (3b) was isolated as white needles $(3.20 \mathrm{~g}, 86 \%)$ after recrystallization from ligroin-toluene (3:1) by reaction of $N$-o-(bromobenzyl) phthalimide $(1 \mathrm{~b}, 3.16 \mathrm{~g} ; 0.01=\mathrm{mol})$ with n-butyllithium $(4.35 \mathrm{~mL} ; 0.01 \mathrm{~mol} / 2.3 \mathrm{M}$ in hexane), $\mathrm{mp} 161.5-62^{\circ} \mathrm{C}$; IR (KBr): $3180,2925,1640,1610,1390$, $1310,1260,1110,1070,1020,950,890,870,730,700 \mathrm{~cm}^{-1} ;{ }^{1} \mathrm{H}$ NMR $\left(300 \mathrm{MHz}, \mathrm{CDCl}_{3}\right): \delta 0.58-1.08\left(\mathrm{~m}, 7, \mathrm{CH}_{3} \mathrm{CH}_{2} \mathrm{CH}_{2}\right), 1.87-2.16(\mathrm{~m}, 2$, $\left.\mathrm{CH}_{2}\right), 3.97(\mathrm{~s}, 1, \mathrm{OH}), 4.60\left(\mathrm{AB}\right.$ pattern, $2, \mathrm{~J}=15 \mathrm{~Hz}$, benzylic $\left.\mathrm{CH}_{2}\right)$, 7.03-7.97 (m, 8, $\mathrm{ArH}) ;{ }^{13} \mathrm{C}$ NMR $\left(75 \mathrm{MHz}, \mathrm{CDCl}_{3}\right): \delta 13.58,22.22$, $25.53,35.93,41.39,91.81,112.39,121.89,122.93,123.51,127.48$, $128.71,129.56,130.08,130.66,132.55,137.09,146.90,168.02$. Anal. Calcd for $\mathrm{C}_{19} \mathrm{H}_{20} \mathrm{BrNO}_{2}$ : C, 60.96; H, 5.35; Br, 21.39; N, 3.74. Found: C, 60.99; H, 5.40; Br, 21.44; N, 3.49.

2-(2-Bromophenylethyl)-3-butyl-3-hydroxyisoindolin-1-one (3c) was isolated as white needles $(3.50 \mathrm{~g}, 90 \%)$ after recrystallization from toluene by reaction of $\mathrm{N}$-o-(bromo- $\beta$-phenylethyl) phthalimide $(1 \mathrm{c}, 3.30 \mathrm{~g} ; 0.01 \mathrm{~mol})$ with $n$-butyllithium $(4.35 \mathrm{~mL} ; 0.01 \mathrm{~mol} / 2.3 \mathrm{M}$ in hexane), $\mathrm{mp} 97.5-98.5^{\circ} \mathrm{C}$; IR (KBr): 3225, 3050, 2950, 1640, 1600, 
$1310,1280,1060,1010,750 \mathrm{~cm}^{-1} ;{ }^{1} \mathrm{H}$ NMR $\left(300 \mathrm{MHz}, \mathrm{CDCl}_{3}\right): \delta 0.77$ $1.32\left(\mathrm{~m}, 7, \mathrm{CH}_{3} \mathrm{CH}_{2} \mathrm{CH}_{2}\right), 2.11\left(\mathrm{t}, 2, \mathrm{~J}=8 \mathrm{~Hz}, \mathrm{CH}_{2}\right), 3.03-3.80(\mathrm{~m}, 4$, $\mathrm{CH}_{2}$, benzylic $\left.\mathrm{CH}_{2}\right), 3.76$ (bd s, $\left.1, \mathrm{OH}\right), 6.92-7.57$ (m, 8, $\left.\mathrm{ArH}\right) ;{ }^{13} \mathrm{C}$ NMR $\left(75 \mathrm{MHz}, \mathrm{CDCl}_{3}\right): \delta 13.84,22.42,25.60,35.09,35.87,38.66$, $91.42,121.69,123.12,124.55,126.31,127.61,128.19,129.36$, $131.11,132.22,132.81,138.65,146.90,167.76$. Anal. Calcd for $\mathrm{C}_{20} \mathrm{H}_{22} \mathrm{BrNO}_{2}: \mathrm{C}, 61.86 ; \mathrm{H}, 5.67 ; \mathrm{Br}, 20.62 ; \mathrm{N}, 3.61$. Found: $\mathrm{C}, 62.04$; $\mathrm{H}, 5.78 ; \mathrm{Br}, 20.77 ; \mathrm{N}, 3.43$.

\section{Conclusion}

Hydroxphthalimidines 3a-c were obtained in good yields with no perceptible halogen-metal exchange by low temperature addition of $n$-butyllithium to $\mathrm{N}$-(o-bromophenyl)- phthalimide and $\mathrm{N}-(\mathrm{o}-$ bromophenylalkyl)phthalimides and were characterized by ${ }^{1} \mathrm{H}$ and ${ }^{13} \mathrm{C}$ NMR, IR, and elemental analysis. This methodology may provide an entry to a variety of heterocyclic systems that may utilize the latent functionalization that subsequent bromine-lithium exchange can provide.

\section{Acknowledgements}

None.

\section{Conflict of interest}

Author declares that there is no conflict of interest.

\section{References}

1. Parham WE, Jones LD, Sayed YJ. Org Chem. 1975;40:2394-2399.

2. Deniau E, Enders D. A new simple and convenient synthesis of 3-substituted phthalimidines. Tetrahedron Lett. 2000;41(14):2347-2350.

3. Heidenbluth K, Toenjes H, Scheffler RJ. Prakt Chem. 1965;30:204-217.

4. Barakat MZ, Shehab SK, El-Sadr MM. J Chem Soc. 1957;4133-4135.

5. Sheehan JC, Bolhoffer WA. An Improved Procedure for the Condensation of Potassium Phthalimide with Organic Halides. J Am Chem Soc. 1950;72(6):2786-2788.

6. Practical grade, stored over $4 \AA$ molecular sieves. 